\title{
Distribution patterns of diurnal raptors in open and forested habitats in south-eastern Brazil and the effects of urbanization
}

\author{
CARLOS EDUARDO, ALENCAR CARVALHO and MIGUEL ÂNGELO MARINI
}

\begin{abstract}
Summary
Diurnal raptors may be highly sensitive to anthropogenic disturbances. We evaluated the diversity and abundance of diurnal raptors at an Atlantic Forest-cerrado transition zone in relation to two habitat types (forest fragments and open habitats) and to urbanization, comparing natural open and forested habitats with corresponding habitats within a large urban area. We sampled 80 points, 20 in each of four habitats (semi-natural and urban forests, seminatural and urban open areas), during 12 months. Diurnal raptors recorded (21 species) included only three out of 10 species with some level of threat in the region. Forested habitats had more species (17) than open habitats (12). Urban areas had only $14(67 \%)$ species, whereas seminatural areas had all 21 species. Diurnal raptors were as abundant in urban areas as in seminatural areas in spite of a loss in species richness in urban areas. A re-analysis without Caracara plancus showed that urban areas had a lower mean number of individuals per point than seminatural areas. Overall species richness usually fluctuated from 14 to 16 species, being slightly higher between January and May than in other months. Overall abundance of diurnal raptors was much higher during summer than during winter. Local extinction may have already occurred for some species of diurnal raptors in the region and will probably shortly include several others. At least $C$. plancus, a habitat generalist, requires further studies and eventually management actions, since it is able to reach high population numbers in urbanized areas. Furthermore, highly sensitive species that were not recorded require further investigation regarding their conservation status.
\end{abstract}

\section{Resumo}

Raptores diurnos podem ser altamente sensíveis a perturbações antropogênicas. Avaliamos a diversidade e a abundância de raptores diurnos em uma região de transição entre Floresta Atlântica e Cerrado em relação a dois tipos de hábitats (fragmentos florestais e hábitats abertos) e à urbanização, comparando hábitats abertos e florestais aos hábitats correspondentes dentro de uma área urbana. Amostramos 80 pontos, 20 em cada um dos quatro hábitats (florestas seminaturais e urbanas, áreas abertas semi-naturais e urbanas) durante 12 meses. Entre os raptores diurnos registrados (21 espécies) estão apenas três das 1o espécies com algum nível de ameaça na região. Mais espécies foram registradas nos hábitats florestados (17) do que nos hábitats abertos (12). Apenas $14(67 \%)$ espécies foram registradas nas áreas urbanas, enquanto as 21 espécies foram registradas nas áreas semi-naturais. Os raptores diurnos foram igualmente abundantes nas áreas urbanas e nas áreas semi-naturais independentemente da perda de espécies nas áreas urbanas. Uma nova análise sem Caracara plancus mostrou que as áreas urbanas tiveram um menor número médio de indivíduos por ponto do que as áreas semi-naturais. A riqueza total de espécies foi de 14 e 16 espécies, em geral, sendo um pouco mais alta entre janeiro e maio do que 
nos outros meses. A abundância total de raptores diurnos foi muito maior durante o verão do que no inverno. Algumas espécies de raptores diurnos já podem estar localmente extintas na região, o que ainda pode ocorrer para várias outras espécies em breve. Pelo menos C. plancus, uma espécie generalista de hábitat, necessita de mais estudos e eventualmente ações de manejo uma vez que pode atingir grandes tamanhos populacionais em áreas urbanizadas. Além disso, espécies altamente sensíveis que não foram registradas necessitam de mais investigações sobre seus status de conservação.

\section{Introduction}

The composition and diversity of bird communities have been used as bioindicators of habitat change (Balent and Courtiade 1992, Lauga and Joachim 1992), with some species of diurnal raptors being highly sensitive to anthropogenic disturbance. However, the response of Neotropical diurnal raptors (Falconiformes) to habitat disturbance is still poorly understood (but see Kattan et al. 1994, Thiollay 1992, 1996, Julien and Thiollay 1996, Alvarez et al. 1996, Rodríguez-Estrella et al. 1998, Renjifo 1999, 2001), in spite of increasing anthropogenic impacts, such as deforestation, habitat fragmentation and logging. Besides disturbance to habitat structure, diurnal raptors are also affected by hunting (Thiollay 1985, 1993), decreasing prey density (Jaksic et al. 1992), environmental contamination (Hickey 1969) and trash consumption (Ellis and Lish 1999). Diurnal raptors may also show strong habitat selection, as studied by Robinson (1994) in Amazonian Peru, and by Julien and Thiollay (1996) in French Guyana, or respond to environmental gradients (Bellocq and Gómez-Insausti 2005).

The Neotropical region has the highest number of Falconiformes in the world, with several species threatened globally (IUCN 2004) or regionally (Machado et al. 1998, IBAMA 2003, Marini and Garcia 2005, Garcia and Marini 2006). Threats are related mostly to low densities and very large territories (Terborgh et al. 1990, Robinson 1994, Julien and Thiollay 1996, Robinson et al. 2000). In Brazil, the Atlantic Forest and the cerrado (savanna-like vegetation) are world conservation hotspots (Myers et al. 200o) and have a small proportion of their undisturbed areas protected by conservation units (Klink and Machado 2005, Tabarelli et al. 2005). Furthermore, several aspects of the biology of Neotropical diurnal raptors are still poorly understood (review in Bierregaard 1995), with mostly anecdotal records from south-east Brazil (e.g. Albuquerque 1995, Sick 1997, Silva 1997, Silva and Olmos 1997). All the above-mentioned characteristics of Neotropical diurnal raptors together with the high levels of deforestation call for urgent studies of raptor responses to habitat disturbance. Thus, we evaluated the diversity and abundance of diurnal raptors at an Atlantic Forest-cerrado transition zone in relation to: (I) two habitats types: forest fragments and open habitats; and (2) urbanization, comparing natural open and forested habitats with corresponding habitats within a large urban area.

\section{Study area}

We sampled diurnal raptors at the Atlantic Forest-cerrado biomes transition zone (Veloso 1966, $\mathrm{Ab}^{\prime}$ Saber 1977), in the cities of Belo Horizonte and Nova Lima, state of Minas Gerais, southeastern Brazil (Figure 1). The transition zone between biomes in this region comprises patches of forests ( $1-1,000$ ha) immersed in a matrix of cerrado (sensu lato) (natural savanna and grassland formations) with variable levels of anthropogenic impacts. The local raptor community is composed of species from both biomes, including Atlantic Forest endemics (Leucopternis lacernulatus and L. polionotus) and a cerrado species (Harpyhaliaetus coronatus). Several species with some level of vulnerability formerly occurred in the region, such as: L. lacernulatus and H. coronatus (globally threatened; IUCN 2004), Accipiter poliogaster, L. polionotus, Spizaetus melanoleucus, Morphnus guianensis, Harpia harpyja and Falco deiroleucus (Nearthreatened; Collar et al. 1994), and Spizaetus tyrannus and Spizaetus ornatus (locally Endangered; Machado et al. 1998). 


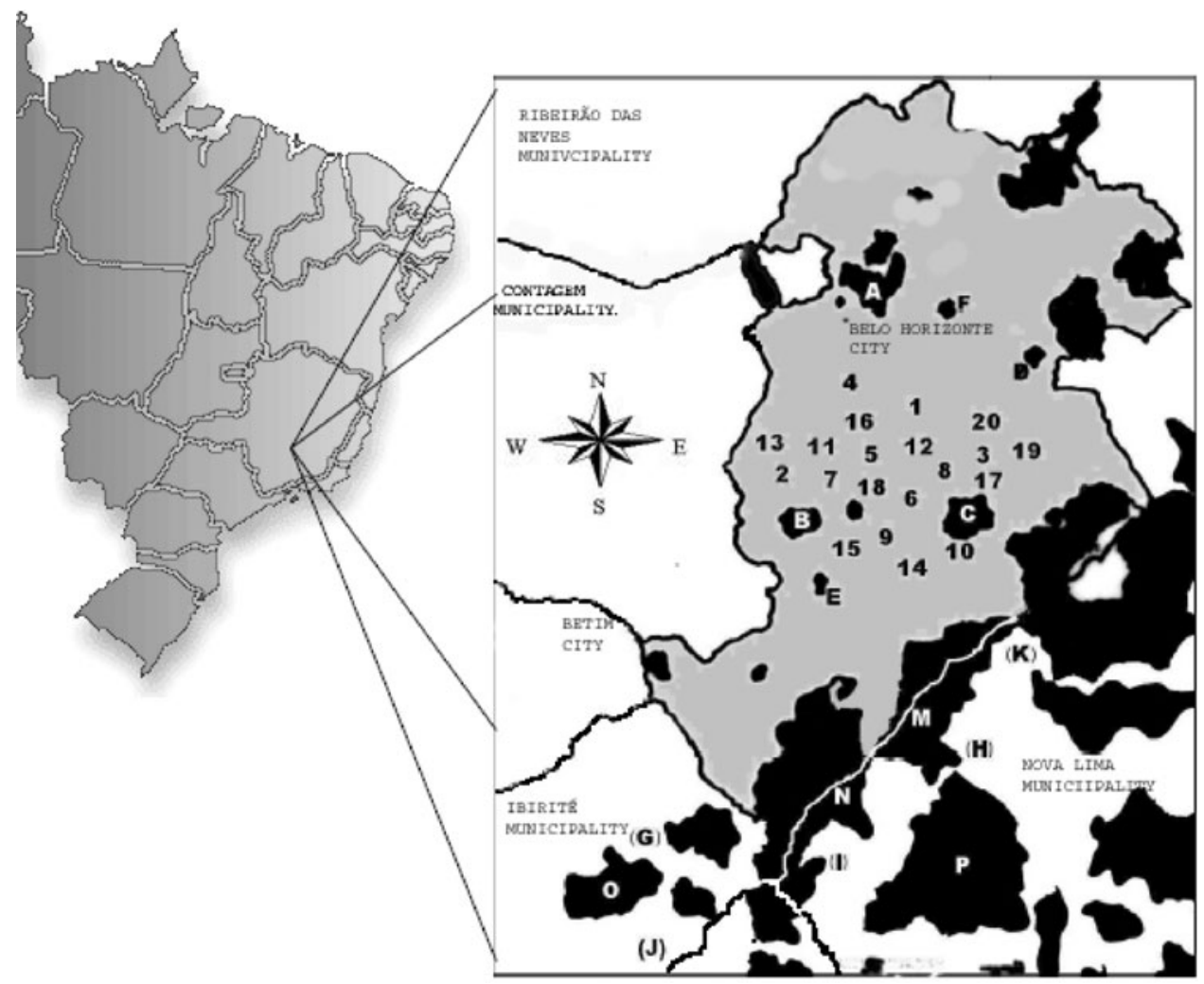

Figure 1 . Map of the study area showing the 16 areas were diurnal raptors were sampled in Belo Horizonte City, Ibirité and Nova Lima cities, Minas Gerais state, Brazil. Forest fragments are in black; open semi-natural habitats are in white. The urban area of Belo Horizonte city is in grey inside the continuous black line. Sampled areas are shown as numbers (urban open areas), letters (forest fragments) and letters in parentheses (open semi-natural areas) according to Table 1.

The climate of the region has two well-defined seasons: a warm rainy summer, OctoberMarch; and a cool dry winter, April-September. Mean annual temperatures range from 18 to $24^{\circ} \mathrm{C}$ and mean annual precipitation is $1,532.2 \mathrm{~mm}$ (Fechos' Meteorological Station - MBR; CETEC 1993).

\section{Methods}

We sampled 8o points, 20 in each of four habitats (semi-natural and urban forests, semi-natural and urban open areas) (Table 1 ). We set points in urban forests (4-50 ha) immersed in a matrix of buildings. We set semi-natural forest points inside fragments (50-40o ha) immersed in a matrix of cerrado grasslands, at least $1 \mathrm{~km}$ from the limits of Belo Horizonte and Nova Lima cities. These semi-natural forests were usually much better preserved than the forests inside the city, which had lower trees, more trails and more clearings. We set urban open area points on street corners or open terrain with scattered planted trees amidst buildings, at least $1 \mathrm{~km}$ from the nearest forest patch. We set semi-natural open area points in a matrix of natural and disturbed cerrado patches. These areas had variable levels of disturbance, and were at least $1 \mathrm{~km}$ from the nearest forest patch and from the city limits. It was not our aim to quantify disturbance 
Table 1. Area, disturbance level, number of observation points and vegetation characteristics of the four types of habitats sampled in the Belo Horizonte and Nova Lima cities, state of Minas Gerais, Brazil.

\begin{tabular}{|c|c|c|c|c|c|c|}
\hline $\begin{array}{l}\text { Observation } \\
\text { area with } \\
\text { corresponding } \\
\text { letter in the } \\
\text { map }\end{array}$ & $\begin{array}{l}\text { Habitat/ } \\
\text { Urbanization }\end{array}$ & $\begin{array}{l}\text { Locality } \\
\text { (coordinates) }\end{array}$ & $\begin{array}{l}\text { Area } \\
\text { (ha) }\end{array}$ & $\begin{array}{l}\text { Disturbance } \\
\text { level }\end{array}$ & $\begin{array}{l}\text { No. of } \\
\text { points }\end{array}$ & Vegetation characteristics \\
\hline A & $\begin{array}{l}\text { Forest/ } \\
\text { Semi-natural }\end{array}$ & $\begin{array}{l}\text { APE Manancial } \\
\text { da Mutuca } \\
20^{\circ} \mathrm{Oo} .74^{\prime} \mathrm{S} \\
043^{\circ} 55.97^{\prime} \mathrm{W}\end{array}$ & 330 & Medium & 4 & $\begin{array}{l}\text { Secondary forest with } \\
\text { trees up to } 90 \text { years old, } \\
\text { canopy of } 10-15 \mathrm{~m} \text {, dense } \\
\text { understorey }\end{array}$ \\
\hline B & $\begin{array}{l}\text { Forest/ } \\
\text { Semi-natural }\end{array}$ & $\begin{array}{l}\text { APE Manancial } \\
\text { de Fechos } \\
20^{\circ} 03.23^{\prime} \mathrm{S} \\
043^{\circ} 95.98^{\prime} \mathrm{W}\end{array}$ & 400 & $\begin{array}{l}\text { Low to } \\
\text { medium }\end{array}$ & 4 & $\begin{array}{l}\text { Old ( } 150 \text { years) secondary } \\
\text { forest, canopy of } 20 \mathrm{~m} \\
\text { with emergent trees up to } \\
30 \mathrm{~m} \text {, open understorey }\end{array}$ \\
\hline $\mathrm{C}$ & $\begin{array}{l}\text { Forest/ } \\
\text { Semi-natural }\end{array}$ & $\begin{array}{l}\text { Parque Estadual } \\
\text { do Rola Moça } \\
20^{\circ} 03 \cdot 78^{\prime} \mathrm{S} \\
043^{\circ} 03 \cdot 36^{\prime} \mathrm{W}\end{array}$ & 100 & $\begin{array}{l}\text { Low to } \\
\text { medium }\end{array}$ & 3 & $\begin{array}{l}\text { Old ( } 150 \text { years) secondary } \\
\text { forest, canopy of } 20 \mathrm{~m} \\
\text { with emergent trees up to } \\
30 \mathrm{~m} \text {, open understorey }\end{array}$ \\
\hline $\mathrm{D}$ & $\begin{array}{l}\text { Forest/ } \\
\text { Semi-natural }\end{array}$ & $\begin{array}{l}\text { APE Manancial } \\
\text { do Barreiro } \\
20^{\circ} 00.36^{\prime} \mathrm{S} \\
043^{\circ} 58.47^{\prime} \mathrm{W}\end{array}$ & 250 & $\begin{array}{l}\text { Low to } \\
\text { medium }\end{array}$ & 9 & $\begin{array}{l}\text { Old ( } 150 \text { years) secondary } \\
\text { forest, canopy of } 20 \mathrm{~m} \\
\text { with emergent trees up to } \\
30 \mathrm{~m} \text {, open understorey }\end{array}$ \\
\hline E & Forest/Urban & $\begin{array}{l}\text { Reserva } \\
\text { Ecológica da PUC } \\
-\mathrm{MG} 19^{\circ} 55.26^{\prime} \mathrm{S}, \\
043^{\circ} 59 \cdot 35^{\prime} \mathrm{W}\end{array}$ & 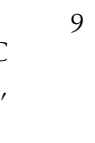 & High & 2 & $\begin{array}{l}\text { Secondary forest with } \\
\text { trees up to } 90 \text { years old, } \\
\text { canopy of } 10-15 \mathrm{~m} \text {, dense } \\
\text { understorey }\end{array}$ \\
\hline $\mathrm{F}$ & Forest /Urban & $\begin{array}{l}\text { Reserva } \\
\text { Ecológica UFMG } \\
19^{\circ} 55 \cdot 36^{\prime} \mathrm{S}, \\
043^{\circ} 58.32^{\prime} \mathrm{W}\end{array}$ & 40 & High & 5 & $\begin{array}{l}\text { Secondary forest with } \\
\text { trees up to } 90 \text { years old, } \\
\text { canopy of } 10-15 \mathrm{~m} \text {, dense } \\
\text { understorey }\end{array}$ \\
\hline G & Forest/Urban & $\begin{array}{l}\text { Horto-Florestal } \\
\text { de Belo } \\
\text { Horizonte } \\
19^{\circ} 53 \cdot 40^{\prime} \mathrm{S}, \\
043^{\circ} 54 \cdot 78^{\prime} \mathrm{W}\end{array}$ & 40 & High & 5 & $\begin{array}{l}\text { Secondary forest with } \\
\text { trees up to } 90 \text { years old, } \\
\text { canopy of } 10-15 \mathrm{~m} \text {, dense } \\
\text { understorey }\end{array}$ \\
\hline $\mathrm{H}$ & Forest/Urban & $\begin{array}{l}\text { Fundação Zoo- } \\
\text { botânica de Belo } \\
\text { Horizonte } \\
19^{\circ} 51.59^{\prime} \mathrm{S}, \\
043^{\circ} 00.23^{\prime} \mathrm{W}\end{array}$ & 30 & High & 4 & $\begin{array}{l}\text { Secondary forest with } \\
\text { trees up to } 90 \text { years, } \\
\text { canopy of } 10-15 \mathrm{~m} \text {, dense } \\
\text { understorey }\end{array}$ \\
\hline I & Forest/Urban & $\begin{array}{l}\text { Mata do } \\
\text { Aeroporto } \\
19^{\circ} 51.00^{\prime} \mathrm{S} \\
043^{\circ} 57.02^{\prime} \mathrm{W}\end{array}$ & 8 & High & 2 & $\begin{array}{l}\text { Secondary forest with } \\
\text { trees up to } 90 \text { years old, } \\
\text { canopy of } 10-15 \mathrm{~m} \text {, dense } \\
\text { understorey }\end{array}$ \\
\hline $\mathrm{J}$ & Forest/Urban & $\begin{array}{l}\text { Parque Estadual } \\
\text { Ursulina } \\
19^{\circ} 53.04^{\prime} \mathrm{S}, \\
043^{\circ} 59.83^{\prime} \mathrm{W}\end{array}$ & 12 & High & 2 & $\begin{array}{l}\text { Secondary forest with } \\
\text { trees up to } 90 \text { years old, } \\
\text { canopy of } 10-15 \mathrm{~m} \text {, dense } \\
\text { understorey }\end{array}$ \\
\hline $\mathrm{L}$ & $\begin{array}{l}\text { Open/ } \\
\text { Semi-natural }\end{array}$ & $\begin{array}{l}\text { APE Manancial } \\
\text { de Fechos } \\
20^{\circ} \mathrm{O} 2.94^{\prime} \mathrm{S} \\
\mathrm{O} 43^{\circ} 57.62^{\prime} \mathrm{W}\end{array}$ & 1,600 & Medium & 4 & $\begin{array}{l}\text { Cerrado of } 150 \text { years } \\
\text { preservation, except for } \\
\text { occasional fires }\end{array}$ \\
\hline
\end{tabular}


Table 1 . Continued.

\begin{tabular}{|c|c|c|c|c|c|c|}
\hline $\begin{array}{l}\text { Observation } \\
\text { area with } \\
\text { corresponding } \\
\text { letter in the } \\
\text { map }\end{array}$ & $\begin{array}{l}\text { Habitat/ } \\
\text { Urbanization }\end{array}$ & $\begin{array}{l}\text { Locality } \\
\text { (coordinates) }\end{array}$ & $\begin{array}{l}\text { Area } \\
\text { (ha) }\end{array}$ & $\begin{array}{l}\text { Disturbance } \\
\text { level }\end{array}$ & $\begin{array}{l}\text { No. of } \\
\text { points }\end{array}$ & Vegetation characteristics \\
\hline M & $\begin{array}{l}\text { Open/ } \\
\text { Semi-natural }\end{array}$ & $\begin{array}{l}\text { Parque Estadual } \\
\text { do Rola Moça } \\
20^{\circ} \mathrm{O} 2.96^{\prime} \mathrm{S}, \\
\mathrm{O} 44^{\circ} \mathrm{Oo.8} 3^{\prime} \mathrm{W}\end{array}$ & 1,500 & Medium & 7 & $\begin{array}{l}\text { Cerrado of } 150 \text { years } \\
\text { preservation, except for } \\
\text { occasional fires }\end{array}$ \\
\hline $\mathrm{N}$ & $\begin{array}{l}\text { Open/ } \\
\text { Semi-natural }\end{array}$ & $\begin{array}{l}\text { APE Manancial } \\
\text { do Barreiro } \\
20^{\circ} \mathrm{O} 2.10^{\prime} \mathrm{S} \\
044^{\circ} 00.25^{\prime} \mathrm{W}\end{array}$ & 1,500 & Medium & 3 & $\begin{array}{l}\text { Cerrado of } 150 \text { years } \\
\text { preservation, except for } \\
\text { occasional fires }\end{array}$ \\
\hline $\mathrm{O}$ & $\begin{array}{l}\text { Open/ } \\
\text { Semi-natural }\end{array}$ & $\begin{array}{l}\text { APE Manancial } \\
\text { da Mutuca } \\
20^{\circ} 00.74^{\prime} \mathrm{S} \\
\mathrm{O} 43^{\circ} 58.89^{\prime} \mathrm{W}\end{array}$ & 1,750 & Medium & 3 & $\begin{array}{l}\text { Cerrado of } 90 \text { years } \\
\text { preservation, except for } \\
\text { occasional fires }\end{array}$ \\
\hline $\mathrm{P}$ & $\begin{array}{l}\text { Open/ } \\
\text { Semi-natural }\end{array}$ & $\begin{array}{l}\text { Serra do Curral } \\
19^{\circ} 57 \cdot 72^{\prime} \mathrm{S} \\
043^{\circ} 55.11^{\prime} \mathrm{W}\end{array}$ & 3,000 & High & 3 & $\begin{array}{l}\text { Disturbed Cerrado with } \\
\text { occasional fires }\end{array}$ \\
\hline $1-20$ & Open/Urban & $\begin{array}{l}\text { Centre of Belo } \\
\text { Horizonte city } \\
19^{\circ} 55.08^{\prime} \mathrm{S}, \\
043^{\circ} 56.35^{\prime} \mathrm{S}\end{array}$ & 30,000 & Very high & 20 & $\begin{array}{l}\text { Mostly buildings, with a } \\
\text { few patches of exotic } \\
\text { grasslands, and planted } \\
\text { trees }\end{array}$ \\
\hline
\end{tabular}

levels of forests and grasslands. However, they were not alike and had intrinsic characteristics of habitats in urban or semi-natural landscapes.

Each of the 20 observation points in the four habitats (total of 80 points) was sampled for raptors (Falconiformes: Accipitridae and Falconidae) once a month, between March 1999 and February 2000. Each point had an observation radius of $500 \mathrm{~m}$. We set points inside forests at least $50 \mathrm{~m}$ away from the forest edge. The observer (C.E.A.C.) sampled each point for 20 minutes after 20 minutes of arrival. Observations, between 06 hoo and 1 ithoo and between 16 hoo and 18hoo, made with binoculars $(8-20 \times 50 \mathrm{~mm})$ totalled 320 hours. Taxonomy follows CBRO (2006) and English names follow Del Hoyo et al. (1994). Raptor identification was based on plumage characteristics, body size, shape and proportions as described in field guides. C.E.A.C. has several years of experience with raptor identification in the field. We considered one point to have more than one individual when two or more individuals could be clearly distinguished due to simultaneous observations, spatial and temporal occurrence at the point, or to different plumage patterns. One observation of a species at a point in two or more months was considered as one individual.

We used non-parametric two-way ANOVAs (Sokal and Rohlf 1981) to test the effects of habitat (forested $\times$ open) and urbanization (urban $\times$ semi-natural) on raptor richness or abundance per point because data had outliers and non-normal distribution. Significance level was set at $P<0.05$.

\section{Results}

Diurnal raptors recorded (2I species; Table 2), included only three (H. coronatus, $L$. lacernulatus and $F$. deiroleucus) out of 10 species with some level of threat in the region (Machado et al. 1998). These three species were rare in the study area, and observed only in semi-natural areas. Similarly, three other species (Falco rufigularis, Ictinia plumbea and 
Harpagus diodon) were also rare in the region and recorded only in semi-natural areas. Herpetotheres cachinnans was also rare and recorded only five times in all habitats except in urban forests.

\section{Influence of habitat}

Forested habitats had more species (17) than open habitats (12) (Table 2). Nine species occurred only in forests, four of which occurred only in semi-natural forests, and always in very low numbers. Four species occurred only in open areas, three of which were recorded only in seminatural open areas. Two of these are rare and/or endangered. Even though the total number of species was similar between open and forested habitats [two-way ANOVA: habitat $\left(\chi^{2}=1.09\right.$, $P>0.05)$, urbanization $\left(\chi^{2}=26.1, P<0.0005\right)$, habitat $\times$ urbanization $\left.\left(\chi^{2}=13.6, P<0.005\right)\right]$ the mean number of species per point was higher in forests [habitat $\left(\chi^{2}=6.12, P<0.025\right)$, urbanization $\left(\chi^{2}=22.4, P<0.005\right)$, habitat $\times$ urbanization $\left.\left(\chi^{2}=13.3, P<0.005\right)\right]$.

Table 2. Habitat preference and estimated number of raptor individuals in each of the four habitat types in the Belo Horizonte and Nova Lima cities.

\begin{tabular}{|c|c|c|c|c|}
\hline \multirow[t]{2}{*}{ Habitat preference } & \multicolumn{2}{|c|}{ Urban habitats } & \multicolumn{2}{|c|}{ Semi-natural habitats } \\
\hline & Open & Forested & Open & Forested \\
\hline \multicolumn{5}{|l|}{ Forest - semi-natural } \\
\hline Falco rufigularis & $\mathrm{Nr}$ & $\mathrm{Nr}$ & $\mathrm{Nr}$ & $\mathrm{R}(2)$ \\
\hline Ictinia plumbea & $\mathrm{Nr}$ & $\mathrm{Nr}$ & $\mathrm{Nr}$ & $\mathrm{R}(1)$ \\
\hline Leucopternis lacernulatus & $\mathrm{Nr}$ & $\mathrm{Nr}$ & $\mathrm{Nr}$ & $\mathrm{R}(2)$ \\
\hline Harpagus diodon & $\mathrm{Nr}$ & $\mathrm{Nr}$ & $\mathrm{Nr}$ & $\mathrm{U}$ \\
\hline \multicolumn{5}{|l|}{ Open - semi-natural } \\
\hline Elanus leucurus & $\mathrm{Nr}$ & $\mathrm{Nr}$ & $\mathrm{U}$ & $\mathrm{Nr}$ \\
\hline Harpyhaliaetus coronatus & $\mathrm{Nr}$ & $\mathrm{Nr}$ & $\mathrm{R}(3)$ & $\mathrm{Nr}$ \\
\hline Falco deiroleucus & $\mathrm{Nr}$ & $\mathrm{Nr}$ & $R(I)^{a}$ & $\mathrm{Nr}$ \\
\hline \multicolumn{5}{|l|}{ Forest } \\
\hline Accipiter striatus & $\mathrm{Nr}$ & $R(I)$ & $\mathrm{Nr}$ & $\mathrm{C}$ \\
\hline Micrastur semitorquatus & $\mathrm{Nr}$ & $\mathrm{R}(2)$ & $\mathrm{Nr}$ & $\mathrm{C}$ \\
\hline Micrastur ruficollis & $\mathrm{Nr}$ & $R(2)$ & $\mathrm{Nr}$ & $\mathrm{C}$ \\
\hline Leptodon cayanensis & $\mathrm{Nr}$ & $\mathrm{U}$ & $\mathrm{Nr}$ & $\mathrm{U}$ \\
\hline Accipiter bicolor & $\mathrm{Nr}$ & $\mathrm{U}$ & $\mathrm{Nr}$ & $\mathrm{C}$ \\
\hline \multicolumn{5}{|l|}{ Open habitats } \\
\hline Buteo melanoleucus & $\mathrm{U}$ & $\mathrm{Nr}$ & $\mathrm{U}$ & $\mathrm{Nr}$ \\
\hline Falco femoralis & $\mathrm{U}$ & $R(I)$ & $\mathrm{U}$ & $\mathrm{Nr}$ \\
\hline Falco sparverius & $\mathrm{U}$ & $R(I)$ & VC & $\mathrm{R}(2)^{\mathrm{a}}$ \\
\hline \multicolumn{5}{|l|}{ Generalists } \\
\hline Carcara plancus & VC & $\mathrm{VC}$ & VC & $\mathrm{U}$ \\
\hline Rupornis magnirostris & $\mathrm{U}$ & VC & VC & $\mathrm{C}$ \\
\hline Milvago chimachima & $\mathrm{U}$ & $\mathrm{VC}$ & $\mathrm{C}$ & $\mathrm{VC}$ \\
\hline Buteo albicaudatus & $\mathrm{U}$ & $\mathrm{U}^{\mathrm{b}}$ & $\mathrm{C}$ & $\mathrm{R}(2)^{\mathrm{b}}$ \\
\hline Buteo brachyurus & $\mathrm{U}$ & $\mathrm{C}$ & $\mathrm{R}(\mathrm{I})$ & $\mathrm{U}$ \\
\hline \multicolumn{5}{|l|}{ Rare everywhere } \\
\hline Herpetotheres cachinnans & $\mathrm{R}(\mathrm{I})$ & $\mathrm{Nr}$ & $\mathrm{R}(\mathrm{I})$ & $\mathrm{R}(3)$ \\
\hline Total no. of species & 9 & 12 & 12 & 16 \\
\hline
\end{tabular}

For infrequently observed species, the number of sightings in each habitat is given in parentheses.

VC, very common ( $>_{1} 8$ observations during the study); C, common (11-18 observations); U, uncommon (410 observations); $\mathrm{R}$, rare $\left(<_{4}\right.$ observations); $\mathrm{Nr}$, not registered.

${ }^{\mathrm{a}}$ At the forest edge.

${ }^{\mathrm{b}}$ Soaring above the forest. 
Forested habitats had more individuals than open habitats (Table 2). The mean number of individuals per point was higher in forests [habitat $\left(\chi^{2}=7.34, P<0.001\right)$, urbanization $\left(\chi^{2}=\right.$ 2.61, $P>0.05)$, habitat $\times$ urbanization $\left.\left(\chi^{2}=5.29, P<0.025\right)\right]$. These patterns of abundance were the same even when Caracara plancus (a species with complex and different abundance changes, see below) was excluded from the analysis [habitat $\left(\chi^{2}=7.86, P<0.005\right)$, urbanization $\left(\chi^{2}=13.2, P<0.005\right)$, habitat $\times$ urbanization $\left(\chi^{2}=5.41, P<0.005\right]$.

A comparison of the four habitats sampled (habitat vs urbanization interactions; see statistics in the above paragraph) reveals a gradient of increasing richness and abundance from open urban areas to forested semi-natural areas (Table 2). Some species, such as the three open-area specialists, did not follow this pattern. Habitat generalists (five species) were at least uncommon in at least three habitats. One species was rare in three habitats and absent from one, being classified as rare everywhere.

\section{Effects of urbanization}

Urbanization led to a loss of one-third of diurnal raptors. Urban areas had only 14 (67\%) species, whereas semi-natural areas had all 21 species (Table 2). Both the total number of species per point [two-way ANOVA: habitat $\left(\chi^{2}=1.09, P>0.05\right)$, urbanization $\left(\chi^{2}=26.1, P<0.0005\right)$, habitat $\times$ urbanization $\left.\left(\chi^{2}=13.6, P<0.005\right)\right]$ and the mean number of species per point [habitat $\left(\chi^{2}=6.12, P<0.025\right)$, urbanization $\left(\chi^{2}=22.41, P<0.005\right)$, habitat $\times$ urbanization $\left(\chi^{2}\right.$ $=13.3, P<0.005)]$ were significantly lower in urban areas than in semi-natural areas. Of the seven species which did not occur in urban areas, five were rare, and two were uncommon even in open or in semi-natural areas. Open or forested urban areas had no species recorded exclusively in them.

Diurnal raptors were as abundant in urban areas as in semi-natural areas in spite of a loss in species richness in urban areas. The mean number of individuals per point did not differ between urban and semi-natural areas [habitat $\left(\chi^{2}=7.34, P<0.001\right)$, urbanization $\left(\chi^{2}=2.61, P>0.05\right)$, habitat $\times$ urbanization $\left.\left(\chi^{2}=5.29, P<0.025\right)\right]$. This lack of difference was probably due to the 12 -fold increase in abundance of $C$. plancus in forested urban areas (mean of 18.3 individuals per month) in relation to forested semi-natural areas (mean of 1.5 individuals per month). A reanalysis without $C$. plancus showed a highly significant difference in mean number of individuals per point [habitat $\left(\chi^{2}=7.86, P<0.005\right)$, urbanization $\left(\chi^{2}=13.2, P<0.005\right)$, habitat $\times$ urbanization $\left(\chi^{2}=5.41, P<0.005\right]$. The abundance of $C$. plancus increased significantly mostly in urban forests in relation to semi-natural forests, but not between urban and seminatural areas [habitat $\left(\chi^{2}=10.4, P<0.005\right)$, urbanization $\left(\chi^{2}=1.62, P>0.10\right)$, habitat $\times$ urbanization $\left(\chi^{2}=3.83, P=0.05\right]$.

\section{Seasonal changes}

Overall species richness fluctuated from 14 to 16 species (except for August: 12 species), being slightly higher between January and May (16 species) than in other months (Table 3). August was the month with the lowest richness and lowest abundance. In agreement with this small variation in species richness is the fact that most diurnal raptors were year-round residents (Table 3). Only four species appear to be winter migrants and two appear to be summer migrants. The few records of $F$. deiroleucus and F. rufigularis do not allow conclusions. One species (Leptodon cayanensis) expanded its occurrence into urban forests only during winter.

Overall abundance of diurnal raptors was much higher during summer than winter, in spite of little change in species richness through the year (Figure 2). This abundance pattern was even more pronounced when $C$. plancus was excluded from the analysis. Overall abundance was highest October-February, with a peak in December with 215 records 
Table 3. Migratory status and number of records of diurnal raptors in the four habitat types by month in Belo Horizonte and Nova Lima cities, Minas Gerais state, Brazil.

\begin{tabular}{|c|c|c|c|c|c|c|c|c|c|c|c|c|}
\hline Species & Jan & Feb & Mar & Apr & May & Jun & Jul & Aug & Sep & Oct & Nov & Dec \\
\hline \multicolumn{13}{|l|}{ Residents } \\
\hline Accipiter bicolor & 9 & 8 & 2 & 1 & 4 & 5 & 2 & 4 & 5 & 7 & 10 & 14 \\
\hline Accipiter striatus & 4 & 8 & 3 & 1 & 1 & 3 & 3 & 4 & 3 & 6 & 5 & 13 \\
\hline Buteo albicaudatus & 5 & 4 & 4 & 8 & 4 & 2 & 2 & 3 & 2 & 6 & 5 & 9 \\
\hline Buteo brachyurus & 8 & 8 & 6 & 7 & 3 & 7 & 8 & 7 & 2 & 4 & 7 & 9 \\
\hline Buteo melanoleucus & 3 & 4 & 3 & o & 2 & 1 & 2 & 1 & 1 & 1 & 2 & 1 \\
\hline Carcara plancus & 27 & 30 & 15 & 14 & 40 & 58 & 32 & 30 & 41 & 53 & 36 & 36 \\
\hline Falco femoralis & 3 & 6 & 3 & 4 & 4 & 7 & 1 & o & 2 & 3 & 4 & 4 \\
\hline Falco sparverius & 10 & 12 & 9 & 8 & 4 & 11 & 7 & 10 & 15 & 11 & 16 & 19 \\
\hline Leptodon cayanensis & 1 & 3 & 1 & 3 & 1 & 1 & 1 & 3 & 2 & 4 & 4 & 6 \\
\hline Micrastur ruficollis & 3 & 6 & 3 & 3 & 1 & o & 3 & $\mathrm{o}$ & 1 & 2 & 2 & 2 \\
\hline Micrastur semitorquatus & 7 & 4 & 4 & 5 & 3 & 4 & 3 & 1 & 3 & 2 & 2 & 3 \\
\hline Milvago chimachima & 32 & 35 & 19 & 27 & 17 & 22 & 21 & 22 & 24 & 24 & 43 & 45 \\
\hline $\begin{array}{l}\text { Rupornis magnirostris } \\
\text { Winter local migrants }\end{array}$ & 22 & 27 & 32 & 29 & 15 & 21 & 15 & 10 & 10 & 22 & 37 & 50 \\
\hline Elanus leucurus & 3 & 6 & 1 & 1 & o & o & o & o & o & o & 2 & 4 \\
\hline Harpagus diodon & 1 & 1 & 1 & 2 & 3 & o & o & $\mathrm{o}$ & o & o & $\mathrm{o}$ & o \\
\hline Harpyhaliaetus coronatus & o & $\mathrm{o}$ & o & o & $\mathrm{O}$ & $\mathrm{o}$ & o & o & 2 & 2 & $\mathrm{o}$ & o \\
\hline $\begin{array}{l}\text { Ictinia plumbea } \\
\text { Summer local migrants }\end{array}$ & 1 & 1 & o & o & o & o & o & o & o & o & o & o \\
\hline Herpetotheres cachinnans & o & o & o & o & 3 & 1 & 2 & 1 & o & o & o & o \\
\hline $\begin{array}{l}\text { Leucopternis lacernulatus } \\
\text { Insufficient data }\end{array}$ & o & o & o & 1 & 2 & o & 1 & o & o & o & o & o \\
\hline Falco rufigularis & o & o & 2 & o & o & 1 & $\mathrm{o}$ & o & o & o & o & o \\
\hline Falco deiroleucus & o & o & o & 1 & o & o & o & o & o & o & o & o \\
\hline
\end{tabular}

Nomenclature follows CBRO (2006).

(Figure 2). Winter abundance was as low (103 and 96 records in July and August, respectively). Most species had peaks in abundance November-February. The peak in abundance for C. plancus, however, occurred during winter (May-June) or early summer (September-October).

\section{Discussion}

Six regionally threatened diurnal raptors (H. harpyja, M. guianensis, S. melanoleucus, $S$. tyrannus, S. ornatus and A. poliogaster) (Machado et al. 1998) might already be locally extinct or extremely rare in the region. All these missing diurnal raptors are large, supporting the fact that large diurnal raptors have high sensitivity to disturbance in areas with high human population densities (Thiollay 1994). Similarly, the decline of four macaws in the Peruvian and Colombian Amazon was related to human population density (Brooks and Begazo 2001).

The disappearance of the largest diurnal raptors is common in disturbed areas formerly covered by native forest (Thiollay 1996). However, two globally threatened species $(H$. coronatus and L. lacernulatus) (IBAMA 2003, IUCN 2004) and one regionally threatened species (F. deiroleucus) (Machado et al. 1998) were still present in the area although in very low numbers. A species (F. deiroleucus) of uncertain conservation status (Bierregaard 1995) was very rare in our study region as well as in the northern Andes (Thiollay 1996), and uncommon in French Guiana (Julien and Thiollay 1996). This species is considered extinct in the wild in the state of Rio Grande do Sul (Fontana et al. 2003) and endangered in the states of Rio de Janeiro (Bergallo et al. 2000) and São Paulo (São Paulo 1998). The conservation status of two other 


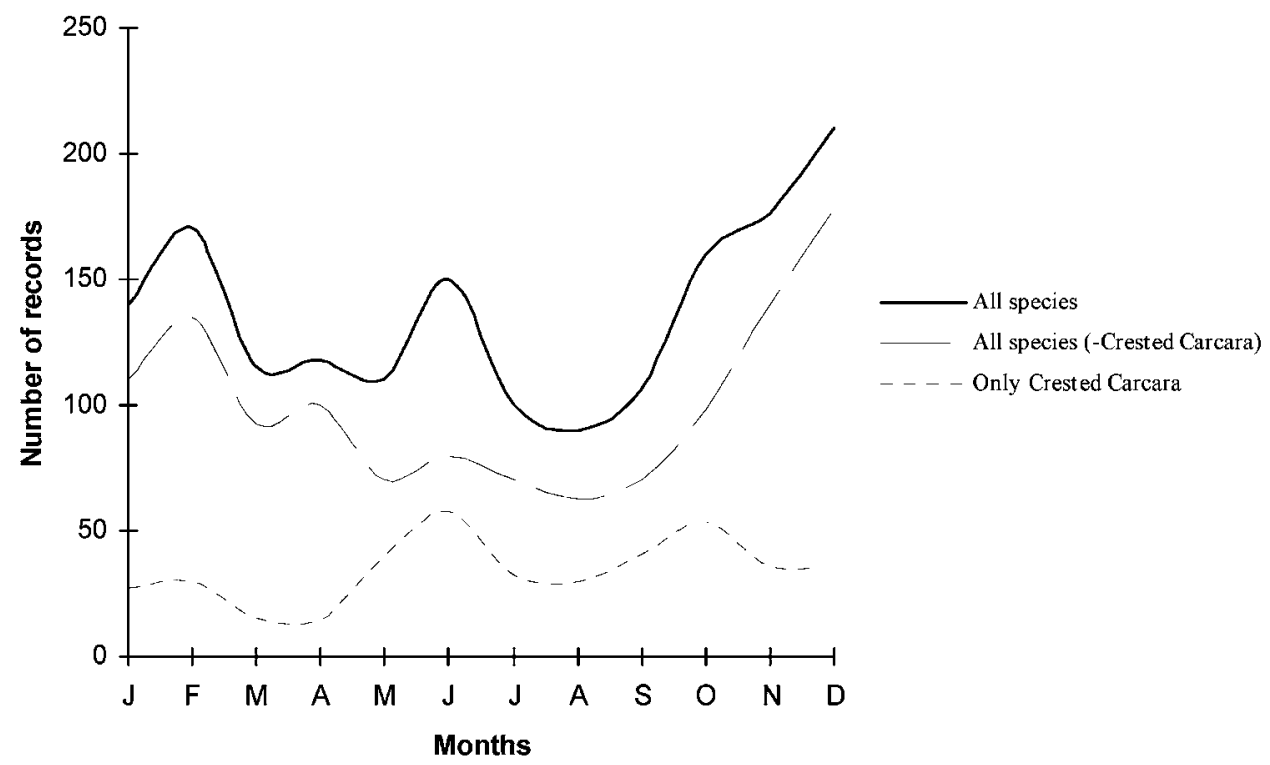

Figure 2. Abundance of diurnal raptors [all species, all species excluding Crested Carcara (Carcara plancus) and only Crested Carcara (C. plancus)] through the year in Belo Horizonte and Nova Lima cities, Minas Gerais state, Brazil. Data for each month are lumped sightings from the four habitats.

species (H. diodon and F. rufigularis) should be re-evaluated in the state of Minas Gerais in spite of being common in some other areas (Robinson 1994, Julien and Thiollay 1996, Thiollay 1996). The second species is already considered endangered in the state of Rio Grande do Sul (Fontana et al. 2003). Hapyhaliaetus coronatus is very sensitive to modification and degradation of open cerrado habitats and to declines in potential prey populations, such as armadillos and young rheas. Disturbed open habitats from the cerrado region have lost several species of birds compared with natural grasslands (Tubelis and Cavalcanti 2000). This species is already considered endangered in five states of Brazil (Machado et al. 1998, São Paulo 1998, Fontana et al. 2003, Mikich and Bérnils 2004, Aleixo 2006). The conservation status of some other species (L. lacernulatus, H. diodon, A. poliogaster and Accipiter striatus) is still poorly known (Bierregaard 1995). The first species is already endangered in four states of Brazil (Machado et al. 1998, São Paulo 1998, Fontana et al. 2003, Mikich and Bérnils 2004). One species (A. striatus) is uncommon in the state of Rio Grande do Sul (Belton 1994) and was rare in riparian forests in the state of Paraná (Loures-Ribeiro and Anjos 2006).

The classification of diurnal raptors into six groups of habitat use reveals that several species have very specific habitat demands, whereas others are habitat generalists. Seven species (seminatural forest and semi-natural open habitat species) were sensitive to urbanization, not occurring even in protected urban forests. Another seven species (forest and open habitat species) were shown to be habitat specialists. Forest specialists occurred in lower numbers within city limits. Diurnal raptors that dwell in urban areas are usually species of open habitats or forest edge (Bird et al. 1996).

The habitat generalists group can be further divided into two subgroups: (a) two species which occurred in all habitats but preferred either open areas (Buteo albicaudatus) or forests (Buteo brachyurus); and (b) three species which were at least common in three habitats (C. plancus, Milvago chimachima and Rupornis magnirostris). These latter three species were also the three most common species using several habitats $200 \mathrm{~km}$ south of our study area (Ribon 2000), and 
are common in other places, such as in the state of Rio Grande do Sul (Belton 1994) and in northern Argentina (Di Giacomo 2005). They were recorded, however, in very low numbers in localities in natural and disturbed cerrado habitats in the Distrito Federal, Brazil (Tubelis and Cavalcanti 2000). Rupornis magnirostris was four times more abundant in pastures and plantations than in forests in sub-Andean forests (Renjifo 2001). It was also more abundant in grasslands than in forest fragments in the state of Paraná (Loures-Ribeiro and Anjos 2006). Herpetotheres cachinnans, an inhabitant of forest edge, cerrado and isolated trees (Sick 1997), occurred in three habitats but always in very low numbers. In the state of Paraná, however, it was rare only in forest fragments and never occurred in riparian corridors, wetlands or grasslands (Loures-Ribeiro and Anjos 2006).

Urbanization is a severe problem for most diurnal raptors. We showed that seven species did not occur within city limits, II were rare or uncommon everywhere and only three were common or very common. The responsiveness to urbanization, however, varied considerably among species. For example, two diurnal raptors (C. plancus and R. magnirostris) were sighted more often in certain urban forests than in semi-natural forests. Population increase of these two species inside urban forests may cause further impacts, such as depletion of potential prey (arthropods, birds and small mammals), or displacement of other smaller diurnal raptors. Carcara plancus proved to be common in urban environments, probably as a result of its ability to use open habitats, and exploit new food resources in cities, mostly garbage. Its omnivorous diet and diverse foraging behaviour (Sick 1997) associated with some tolerance to humans may explain its ability to explore urban resources. Our results are in agreement with RodríguezEstrella (1996), who stated that C. plancus is one of the species that benefits from human activities in Mexico. We recommend that the abundance of $C$. plancus in urban habitats should be further explored as a potential tool and bioindicator of habitat alteration.

Of the four species (E. leucurus, I. plumbea, H. coronatus and H. diodon) that we recorded in the region only during summer, the first three are considered partially migratory, but the last is presumed to be sedentary in absence of data to the contrary (Bierregaard 1995). Thus, at least in our study region, $H$. diodon seems to be a migrant, and L. lacernulatus and H. cachinnans should also be considered locally migrant, since we recorded them only during winter. The last species was considered resident, although uncommon, in northern Argentina (Di Giacomo 2005). Three species (A. striatus, B. brachyurus and F. femoralis), classified by Bierregaard (1995) as of uncertain migratory behaviour, occurred year-round in our study region, and seem to be sedentary. The last two were also considered resident in northern Argentina (Di Giacomo 2005). However, Falco femoralis was little recorded between July and September in our study site. The seasonal occurrence of four species (L. cayanensis, B. melanoleucus, M. semitorquatus and $F$. femoralis) in the city may be related to seasonal dispersal or seasonal home range expansion as reported by Newton (1979).

Detectability of diurnal raptors at observation points within city limits might have been only partially affected by buildings. Points were set at clearings and buildings around census points were not too high. If observation points were established on the top of buildings, detectability of flying diurnal raptors would have been higher, whereas detectability of perched diurnal raptors would have been lower than in natural areas. Furthermore, points inside forests have the same detectability in both urban and semi-natural forests.

The disappearance or low abundance of several species of diurnal raptors in our study region is probably related to several factors, including hundreds of years of forest destruction and fragmentation, hunting, persecution, and reduction of prey populations. Forest fragmentation is probably the most important anthropogenic threat to bird populations (Thiollay 1994). In an Amazonian forest fragmentation study, three species of forest diurnal raptors (Accipiter superciliosus, Micrastur ruficollis and Harpagus bidentadus) disappeared from forest patches of I ha, but the last two were still present in patches of 10 ha (Bierregaard and Lovejoy 1989). Also, in sub-Andean forest fragments, M. ruficollis became regionally extinct and M. semitorquatus became extinct in fragments (Renjifo 1999). Several species of birds have disappeared from forest 
fragments in our study region (Maldonado-Coelho and Marini 2000) or from other similar forests in the state of Minas Gerais (Christiansen and Pitter 1997, Ribon 1998, Marini 2001). Forest species suffer more from habitat disturbance since primary forests have been disturbed, losing several species, as has been reported elsewhere (Thiollay 1992, 1996, Jullien and Thiollay 1996).

Local extinction may have already occurred for some species of diurnal raptors in the region and will probably shortly include several others unless negative anthropogenic impacts, mostly deforestation, are halted soon. Urban habitats may be used by some more sensitive species at least during part of the year, but these will not provide enough habitat to support large populations. At least $C$. plancus requires further studies and eventually management action, since it is able to reach high population numbers in urbanized areas. Special attention should be given to the potential negative impacts it may cause on the few remaining patches of natural habitats in urban areas. Furthermore, highly sensitive species such as $A$. superciliosus, $H$. bidentadus, $H$. harpyja, M. guianensis, S. melanoleucus, S. tyrannus, S. ornatus and A. poliogaster that were not rerecorded require further investigation about their conservation status.

\section{Acknowledgements}

This study was partially funded by CNPq. M.Â.M. held a researcher fellowship from CNPq. We thank property owners, especially COPASA, for authorizations to work on lands they own or manage. We thank Charles Duca, Lemuel Leite and anonymous reviewers for criticisms.

\section{References}

Ab'Saber, A. N. (1977) Os domínios morfoclimáticos na América do Sul. Bol. Inst. Geogr. USP 52: 1-21.

Albuquerque, J. L. B. (1995) Observations of rare raptors in the southern Atlantic rainforest of Brazil. J. Field Ornithol. 66: $363-369$.

Aleixo, A. coord. (2006) Oficina de trabalho "Discussão e elaboração da lista de espécies ameaçadas de extinção no estado do Pará". Technical Report "Projeto Biota Pará". Belém: Museum Paraense Emilio Goeldi.

Alvarez, E., Ellis, H. E., Smith, D. G. and Larue, C. T. (1996) Diurnal raptors in the fragmented rain forest of the Sierra Imataca, Venezuela. Pp. 263-273 in D. M. Bird, D. Varland and J. J. Negro, eds. Raptors in human landscapes: adaptations to built and cultivated environments. London: Academic Press.

Balent, G. and Courtiade, B. (1992) Modelling bird communities/landscape patterns relationships in a rural area of South-western France. Landscape Ecol. 6: 195-211.

Bellocq, M. I. and Gómez-Insausti, R. (2005) Raptorial birds and environmental gradients in the southern Neotropics: a test of species-richness hypotheses. Austral. Ecol. 30: 892-898.

Belton, W. (1994) Aves do Rio Grande do Sul: distribuição e biologia. São Leopoldo: Ed. Unisinos.

Bergallo, H. G., Rocha, C. F. D., Alves, M. A. S. and Van Sluys, M., eds. (2000) A fauna ameaçada de extinção do estado do Rio de Janeiro. Rio de Janeiro: Editora da Universidade do Estado do Rio de Janeiro.

Bierregaard, R. O. Jr (1995) The biology and conservation status of Central and South American Falconiformes: a survey of current knowledge. Bird Conserv. Int. 5: 325-340.

Bierregaard, R. O. Jr and Lovejoy, T. E. (1989) Effects of forest fragmentation on Amazonian understory bird communities. Acta Amaz. 19: 215-241.

Bird, D. M., Varland, D. and Negro, J. J. (1996) Raptors in humans landscapes: adaptations to built and cultivated environments. London: Academic Press.

Brooks, D. M. and Begazo, A. J. (2001) Macaw abundance in relation to human 
population density in the western Amazon Basin. Pp. 427-433 in J. Marzluff, R. Bowman and R. Donnelly, eds. Avian ecology and conservation in an urbanizing world. Boston: Kluwer Academic.

CBRO (Comitê Brasileiro de Registros Ornitológicos) (2006) Comitê Brasileiro de Registros Ornitológicos, São Paulo, Brazil. Available from: http: www. ib.usp.br/cbro (accessed February 2006).

CETEC (1993) Desenvolvimento de metodologia para recuperação do revestimento florístico natural em áreas de proteção das captações de água da COPASA na região metropolitana da grande Belo Horizonte. Belo Horizonte: Fundação Centro Tecnológico de Minas Gerais (CETEC) (Technical report).

Christiansen, M. C. and Pitter, E. (1997) Species loss in forest bird community near Lagoa Santa in Southeastern Brazil. Biol. Conserv. 80: 23-32.

Collar, N. J., Crosby, M. J. and Stattersfield, A. J. (1994) Birds to watch 2: the world list of threatened birds. Cambridge, U.K.: International Council for Bird Preservation (Techn. Publ. 8).

Del Hoyo, J., Elliot, A. and Sargatal, J., eds. (1994) Handbook of birds of the world. Volume 2. Barcelona: Lynx Edicions.

Di Giacomo, A. G. (2005) Aves de la Reserva El Bagual. Pp. $201-465$ in A. G. Di Giacomo and S. F. Krapovickas, eds. Historia natural y paisage de la Reserva El Bagual, provincial de Formosa, Argentina. Buenos Aires: Temas de Naturaleza y Conservación (Monografía de Aves Argentinas No. 4).

Ellis, D. H. and Lish, J. W. (1999) Trashcaused mortality in Mongolian raptors. Ambio 28: 536-537.

Fontana, C. S., Bencke, G. A. and Reis, R. E., eds. (2003) Livro vermelho da fauna ameaçada de extinção no Rio Grande do Sul. Porto Alegre: EDIPUCRS.

Garcia, F. I. and Marini, M. Â. (2006) Estudo comparativo das listas global, nacional e estaduais de aves ameaçadas no Brasil. Natureza \& Conservação 4(2): 24-49.

Hickey, J. J., ed. (1969) Peregrine falcon populations: their biology and decline.
Madison, Milwaukee, and London: University of Wisconsin Press.

IBAMA (Instituto Brasileiro de Meio Ambiente e dos Recursos Naturais Renováveis) (2003) Lista de espécies da fauna ameaçada de extinção. Instrução Normativa $n$ 3, de 27 de Maio de. 2003, Brasília: IBAMA, Ministério do Meio Ambiente.

IUCN (2004) 2004 IUCN Red List of threatened species. Gland, Switzerland: IUCN. Available from: http://www.redlist. org (accessed December 2004).

Jaksic, F. M., Jiménez, J. E., Castro, S. A. and Feinsinger, P. (1992) Numerical and functional response of predators to a long-term decline in mammalian prey at a semiarid Neotropical site. Oecologia 89: 90-101.

Julien, M. and Thiollay, J. M. (1996) Effects of rain forest disturbance and fragmentation: comparative changes of the raptor community along natural and humanmade gradients in French Guiana. J. Biogeogr. 23: 7-25.

Kattan, G. H., Alvarez-López, H. and Giraldo, M. (1994) Forest fragmentation and bird extinctions: San Antonio eighty years later. Conserv. Biol. 8: 138-146 .

Klink, C. A. and Machado, R. B. (2005) Conservation of the Brazilian cerrado. Conserv. Biol. 19: 707-713.

Lauga, J. and Joachim, J. (1992) Modelling the effects of forest fragmentation in certain forest breeding birds. Landscape Ecol. 6: 183-193.

Loures-Ribeiro, A. and Anjos, L. (2006) Falconiformes assemblages in a fragmented landscape of the Atlantic Forest in southern Brazil. Braz. Arch. Biol. Technol. 49: 149-162.

Machado, A. B. M., Fonseca, G. A. B., Machado, R. B., Aguiar, L. M. S. and Lins, L. V. (1998) Livro vermelho das espécies ameaçadas de extinção da fauna de Minas Gerais. Belo Horizonte: Fundação Biodiversitas.

Maldonado-Coelho, M. and Marini, M. Â. (2000) Effects of forest fragment size and successional stage on mixed-species bird flocks in southeastern Brazil. Condor 102: 585-594. 
Marini, M. Â. (2001) Effects of forest fragmentation on birds of the cerrado region, Brazil. Bird Conserv. Int. 11: 11-23.

Marini, M. Â. and Garcia, F. I. (2005) Bird conservation in Brazil. Conserv. Biol. 19: $665-671$.

Marini, M. Â, Aguilar, T. M., MaldonadoCoelho, M., Andrade, R. D., Leite, L. O., Anciães, M., Carvalho, C. E. A., Duca, C., Sebaio, G. F. and Gonçalves, J. (2007) Biologia da nidificação de algumas aves dos Municípios de Belo Horizonte e Nova Lima, Minas Gerais, Brasil. Ararajuba, Rev. Bras. Ornitol. (In press).

Mikich, S. B. and Bérnils, R. S. (2004) Livro vermelho da fauna ameaçada no estado do Paraná. Curitiba: Instituto Ambiental do Paraná.

Myers, N., Mittermeier, R. A., Mittermeier, C. G., Fonseca, G. A. B. and Kent, J. (2000) Biodiversity hotspots for conservation priorities. Nature 403: 853-858.

Newton, I. (1979) Population ecology of raptors. Berkhamsted, T. \& A. D. Poyser.

Renjifo, L. M. (1999) Composition changes in a subandean avifauna after long-term forest fragmentation. Conserv. Biol. 13: 1124-1139.

Renjifo, L. M. (2001) Effect of natural and anthropogenic landscape matrices on the abundance of subandean bird species. Ecol. Applic. 11: 14-31.

Ribon, R. (1998) Fatores que influenciam a distribuição da avifauna em fragmentos de Mata Atlântica nas montanhas de Minas Gerais MSc Dissertation, Belo Horizonte: Universidade Federal de Minas Gerais.

Ribon, R. (2000) Lista preliminar da avifauna do Município de Ijaci, Minas Gerais. Rev. Ceres 47: 665-682.

Robinson, S. K. (1994) Habitat selection and foraging ecology of raptors in Amazonian Peru. Biotropica 26: 443-458.

Robinson, W. D., Brawn, J. D. and Robinson, S. K. (2000) Forest bird community structure in central Panama: influence of spatial scale and biogeography. Ecol. Monogr. 70 : 209-235.

Rodríguez-Estrella, R. (1996) Response of Common Black Hawks and Crested Caracaras to human activities in Mexico. Pp. $356-363$ in D. M. Bird, D. Varland and
J. J. Negro, eds. Raptors in human landscapes: adaptations to built and cultivated environments. London: Academic Press.

Rodríguez-Estrella, R., Donázar, J. A. and Hiraldo, F. (1998) Raptors as indicators of environmental change in the scrub habitat of Baja California Sur, Mexico. Conserv. Biol. 12: 921-925.

São Paulo (1998) Fauna ameaçada no estado de São Paulo. São Paulo: Série Documentos Ambientais. Secretaria do Meio Ambiente. Sick, H. (1997) Ornitologia Brasileira. Rio de Janeiro: Editora Nova Fronteira.

Silva, R. S. (1997) Ecology and behavior of wintering Falco peregrinus (Falconiformes: Falconidae) in Southeastern Brazil. Ararajuba, Rev. Bras. Ornitol. 5: 203-208.

Silva, R. S. and Olmos, F. (1997) Parabuteo unicinctus (Falconiformes: Accipitridae) na Baixada Santista, Litoral de São Paulo, Brasil. Ararajuba, Rev. Bras. Ornitol. 5: 76-79.

Sokal, R. R. and Rohlf, F. J. (1981) Biometry: the principles and practice of statistics in biological research. Second edition. New York: Freeman.

Tabarelli, M., Pinto, L. P., Silva, J. M. C., Hirota, M. and Bedê, L. (2005) Challenges and opportunities for biodiversity conservation in the Brazilian Atlantic Forest. Conserv. Biol. 19: 695-700.

Terborgh, J., Robinson, S. K., Parker, T. A. III, Munn, C. A. and Pierpont, N. (1990) Organization of an Amazonian bird community. Ecol. Monogr. 60: 213-238.

Thiollay, J. M. (1985) Raptor community structure of a primary rain forest in French Guiana and effect of human hunting pressure. J. Raptor Res. 18: 117-122.

Thiollay, J. M. (1992) Influence of selective logging on bird species diversity in a Guianan rain forest. Conserv. Biol. 6: $47-63$.

Thiollay, J. M. (1993) Response of a raptor community to shrinking area and degradation of tropical rain forest in the south western Ghâts (India). Ecography 16: 97-110.

Thiollay, J. M. (1994) A world review of tropical forest raptors: current trends, research objectives and conservation 
strategy. Pp. 231-238 in B. U. Meyburg and R. D. Chancellor, eds. Raptor conservation today. London: WWGBP/The Pica Press.

Thiollay, J. M. (1996) Distributional patterns of raptors along altitudinal gradients in the northern Andes and effects of forest fragmentation. J. Trop. Ecol. 12: 535-560.
Tubelis, D. P. and Cavalcanti, R. B. (2000) A comparison of bird communities in natural and disturbed non-wetland open habitats in the Cerrado's central region, Brazil. Bird Conserv. Int. 10: 331-350.

Veloso, H. P. (1966) Atlas florestal do Brasil. Rio de Janeiro: Ministério da Agricultura.

\section{CARLOS EDUARDO, ALENCAR CARVALHO}

S.O.S. FALCONIFORMES, Rua Odilon Braga, 1370, Belo Horizonte, MG, 30310-390, Brazil.

\section{MIGUEL ÂNGELO MARINI*}

Departamento de Zoologia, Universidade de Brasília, 70.910-9oo, Brasília, DF, Brazil.

*Author for correspondence; e-mail:marini@unb.br

Received 23 December 2005; revision accepted 5 February 2007 